\title{
ANALISIS MITIGASI BENCANA TANAH LONGSOR DAN METODE PENGENDALIANNYA (STUDI KASUS PROYEK JALAN DI JAMBI)
}

\author{
Edric Suryajaya ${ }^{1}$ dan Andryan Suhendra ${ }^{2}$ \\ ${ }^{\text {I}}$ Program Studi Sarjana Teknik Sipil, Universitas Tarumanagara, Jl. Letjen S. Parman No.1 Jakarta \\ Email:edricsur@gmail.com \\ ${ }^{2}$ Program Studi Sarjana Teknik Sipil, Universitas Tarumanagara, Jl. Letjen S. Parman No.1 Jakarta \\ Email:andryansuhendra@yahoo.com
}

\begin{abstract}
ABSTRAK
Provinsi Jambi merupakan salah satu wilayah di Indonesia merupakan yang rawan bencana tanah longsor. Tanah longsor dapat dipicu oleh berbagai faktor, yaitu gempa, vegetasi dan iklim. Kenaikan muka air tanah menyebabkan tanah menjadi jenuh, sehingga kuat geser tanah berkurang. Analisis kestabilan lereng dibutuhkan untuk mengetahui faktor keamanan dari bidang longsor yang potensial. Analisis kestabilan menggunakan metode elemen hingga, sehingga pemodelan dapat dilakukan lebih kompleks mulai dari tahapan konstruksi hingga kenaikan muka air tanah. Pada saat melakukan analisis kestabilan lereng, kondisi lereng sebelum dan sesudah diberi perkuatan akan dikombinasikan dengan muka air tanah yang bervariasi, muka air tanah dinaikan sebesar $1 \mathrm{~m}$ dan $2 \mathrm{~m}$ dari kondisi awal. Hal ini bertujuan untuk mengetahui pengaruh fluktuasi muka air tanah terhadap kestabilan. Dari hasil analisis yang dilakukan pada lereng alami di proyek jalan kerinci sangaran agung, Provinsi Jambi, didapatkan nilai faktor keamanan 0,8779, hal ini menunjukkan lereng tersebut tidak stabil sehingga membutuhkan perkuatan. Kemudian dilakukan perkuatan lereng menggunakan terasering, bronjong, dan soil nailing. Dari hasil analisis faktor keamanan pada lereng yang sudah diberi perkuatan, bronjong dipilih sebagai metode pengendalian tanah longsor yang sesuai. Bronjong dipilih karena lebih stabil terhadap fluktuasi muka air tanah, hal ini dapat dilihat dari nilai faktor keamanan tetap diatas 1,5 . Kemudian pada permukaan yang tidak diberi perkuatan, ditanami rumput vetiver untuk membantu pencegahan erosi pada tanah.
\end{abstract}

Kata kunci: mitigasi, tanah longsor, faktor keamanan, muka air tanah, perkuatan

\section{PENDAHULUAN}

\section{Latar Belakang}

Indonesia merupakan salah satu negara yang memiliki wilayah geografis yang rawan bencana tanah longsor. Dalam berberapa tahun terakhir, daya rusak maupun intensitas dari tanah longsor di Indonesia semakin mengingkat, sehingga kerugian yang ditimbulkanpun semakin meningkat. Untuk itu diperlukan suatu mitigasi atau suatu tindakan untuk mengurangi dampak bencana tersebut. Secara umum mitigasi dapat dilakukan secara struktural dengan berfokus pada perbaikan/perkuatan lereng tersebut ataupun secara nonstruktural dengan berfokus pada edukasi masyarakat di sekitar lereng. Tanah longsor sendiri dapat diakibatkan oleh berberapa faktor, seperti bentuk lereng, vegetasi, gempa bumi, dan iklim pada lereng tersebut.

Pada penelitian ini akan dibahas mengenai faktor-faktor penyebab kelongsoran tersebut, khususnya pengaruh dari iklim melalui modifikasi muka air tanah. Kemudian akan dilakukan mitigasi terhadap lereng tersebut dengan menggunakan metode terasering, bronjong, soil nailing dan rumput vetiver.

\section{Batasan Masalah}

Dalam penelitian ini, batasan-batasan masalah yang digunakan sebagai berikut:

1. Analisis metode pengendalian kelongsoran tanah menggunakan terasering, bronjong, dan soil nailing.

2. Analisa ini dilakukan untuk proyek di Jambi.

3. Analisa menggunakan program elemen hingga.

4. Perhitungan dilakukan dengan mengabaikan beban dinamis. 


\section{Rumusan Masalah}

Rumusan masalah yang akan dibahas ialah:

1. Melakukan peninjauan mengenai faktor-faktor penyebab kelongsoran tanah.

2. Melakukan perhitungan kestabilan lereng sebelum diberikan perkuatan dan setelah diberikan perkuatan terasering, bronjong, dan soil nailing.

3. Melakukan perhitungan angka faktor keamanan dengan berbagai macam level muka air tanah.

4. Melakukan analisis dan perbandingan dari tiga metode pengendalian tanah longsor dengan level muka air yang bervariasi.

\section{Tujuan Penelitian}

Tujuan dari penelitian ini adalah untuk mengetahui pengaruh kenaikan muka air tanah terhadap kestabilan lereng dan mendesain terasering, bronjong, soil nailing, serta rumput vetiver sebagai metode pengendaliannya.

\section{Faktor-Faktor Penentu Kepekaan Tanah Terhadap Longsor}

Dalam upaya mitigasi terhadap kelongosoran tanah, diperlukan pemahaman komprehensif mengenai penyebabpenyebab kelongsoran tersebut. Pemahaman mengenai faktor-faktor kelongsoran harus disesuaikan dengan lokasi lereng tersebut, sehingga didapatkan hasil analisis yang sesuai dengan kebutuhan lapangan. Dalam penelitian ini, faktor-faktor yang akan dibahas adalah lereng, gempa bumi, vegetasi dan iklim.

Indonesia berada di cincin api dunia, hal ini menyebabkan Indonesia terdiri dari lereng-lereng. Lereng adalah suatu bidang di permukaan tanah yang menghubungkan permukaan tanah yang lebih tinggi dengan permukaan yang lebih rendah. Makin curam lereng makin besar pula volume dan kecepatan aliran permukaan yang berpotensi menyebabkan erosi. Selain kecuraman, panjang lereng juga menentukan besarnya longsor dan erosi. Makin panjang lereng, erosi yang terjadi makin besar. Pada lereng $>40 \%$ longsor sering terjadi, terutama disebabkan oleh pengaruh gaya gravitasi.

Kemudian posisi Indonesia yang berada di cincin api dunia juga membuat Indonesia rawan gempa bumi. Gempa merupakan suatu bentuk pembebanan dinamis yang terjadi pada tanah. Gempa sangat berpengaruh terhadap kestabilan tanah apabila terjadi gempa bumi, yang pertama merasakan getaran adalah tanah disekeliling pusat gempa. Getaran akibat gempa kemudian disebarkan kesegala penjuru, selama getaran menjalar dari pusat gempa sampai ke permukaan tanah maka faktor tanah sebagai penghantar getaran mempunyai peran yang sangat penting. Secara umum gempa bumi mempengaruhi stabilitas lereng dengan dua cara yaitu:

1. Percepatan dari gerakan tanah saat gempa terhadap tanah merupakan variasi gaya-gaya siklis

2. Regangan siklis yang disebabkan dari pembebanan gempa dapat mereduksi kuat geser tanah

Reduksi kuat geser dapat menyebabkan terjadinya mass movement pada tanah lereng. Menurut teori mohr coloumb, kuat geser suatu tanah ditentukan oleh kohesi (c) dan sudut geser $(\phi)$ tanah tersebut. Kohesi dapat diartikan sebagai daya lekat antar partikel butiran tanah, semakin tinggi kohesi maka semakin lekat ikatan antar partikel butiran tanah, hal ini akan membuat tanah lebih kuat menahan tegangan-tegangan yang dapat menyebabkan kelongsoran lereng. Sedangkan sudut geser dapat diartikan sebagai gesekan antar partikel butiran tanah, semakin tinggi sudut geser maka semakin besar gesekan antar partikel yang akan membuat partikel butiran tanah akan lebih sulit untuk bergeser.

Kemudian posisi Indonesia yang berada pada cincin api dunia juga membuat Indonesia memiliki banyak gunung api. Hal ini yang membuat tanah-tanah di Indonesia subur, sehingga banyak terjadi penggundulan hutan atau alih fungsi lahan menjadi lahan pertanian. Pada umumnya vegetasi pertanian dapat mengurangi kestabilan lereng karena vegetasi pertanian biasanya memiliki akar-akar yang pendek. Pengertian vegetasi sendiri dalam ekologi adalah istilah untuk keseluruhan komunitas tetumbuhan. Vegetasi merupakan bagian hidup yang tersusun dari tetumbuhan yang menempati suatu ekosistem. Beraneka tipe hutan, kebun, padang rumput, dan tundra merupakan contoh-contoh vegetasi, akan tetapi tidak semua vegetasi cocok untuk menstabilkan suatu lereng. Vegetasi pada lereng dapat mempengaruhi kestabilan lereng dengan cara:

1. Mempengaruhi kekuatan stabilitas dari lereng dengan akar-akar tanaman, berat dari tanaman diatasnya dan kemampuan untuk mengurangi efek beban angin (Ziemer, 1981; Tsukamoto, 1990; Sidle, 1991; Bischetti et al., 2004; Medicus, 2009). Perkuatan lereng yang dihasilkan oleh akar-akar tanaman dapat dirumuskan dengan 3 mekanisme: akar sebagai jangkar, sebagai sokongan lateral dengan melintasi titik-titik lemah pada lereng dan sebagai benang panjang pengikat massa tanah (Ziemer, 1981). Menurut Abe dan Ziemer (1991) kuat geser tanah meningkat dengan meningkatnya konsentrasi akar. Kuat tarik dari akar akan menahan tegangan geser yang terjadi pada tanah sampai titik dimana serat fiber pada akar mulai retak.

2. Mempengaruhi hidrologi suatu lereng dengan mengurangi gaya yang ditimbulkan dari rintikan hujan, intersepsi hujan, evapotranspirasi, tekanan air pori, kuat hisap tanah, jumlah dan volume pori-pori (Markart et al., 2004; 
Markart et al., 2006 ). Siklus hidrologi pada lereng yang dipengaruhi oleh vegetasi dimulai dari intersepsi. Intersepsi berarti proses presipitasi yang terjadi pada daerah lereng dihambat oleh puncak-puncak tumbuhan. setelah terjadi intersepsi, tumbuhan mulai melakukan proses tranpirasi. Transpirasi adalah proses penguapan air pada tumbuhan kembali ke atmosfer. Vegetasi biasanya juga dapat mengurangi runoff yang berlebihan melalui proses infiltrasi dengan meningkatkan jumlah dan volume pori-pori tanah (Markart et al., 2004 ). Pengaruh vegetasi terhadap vegtasi ini akan membuat erosi pada permukaan berkurang dan tanah lebih tidak jenuh.

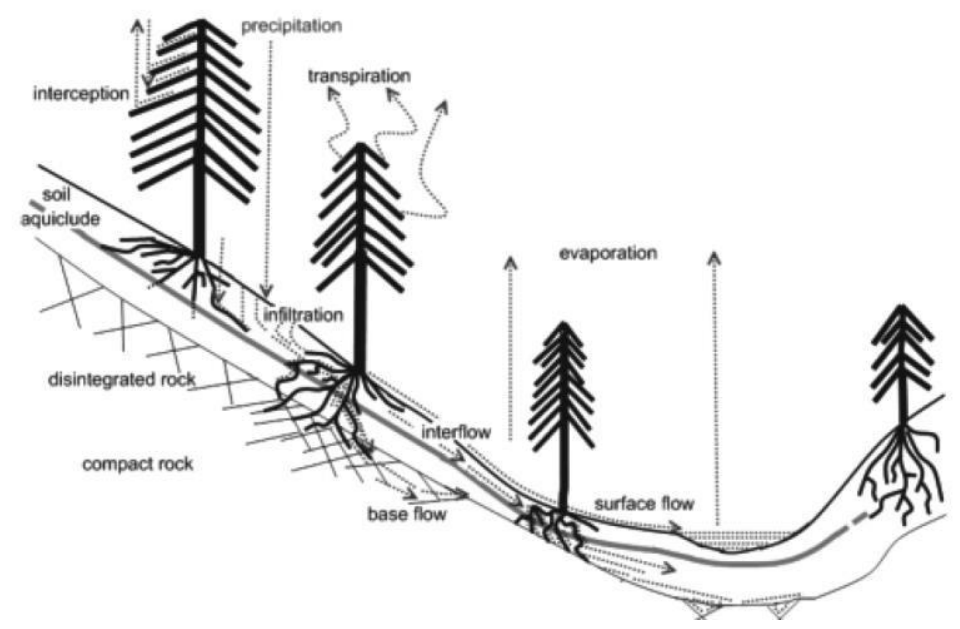

Gambar 1. Siklus Hidrologi pada Lereng dengan Vegetasi (Steinacher, 2009)

Maka dari itu, menurut kementrian pertanian, sangat dianjurkan menanam jenis tanaman berakar dalam, yang dapat menembus lapisan kedap air, mampu merembeskan air ke lapisan yang lebih dalam, dan mempunyai massa yang relatif ringan. Jenis tanaman yang dapat dipilih di antaranya adalah sonokeling, akar wangi, flemingia, kayu manis, kemiri, cengkeh, pala, petai, jengkol, melinjo, alpukat, kakao, kopi, teh, dan kelengkeng.

Kemudian Indonesia juga dilewati garis khatulistiwa. Hal ini membuat Indonesia hanya memiliki 2 musim dan memiliki curah hujan yang tinggi. Curah hujan adalah salah satu unsur iklim yang besar perannya terhadap kejadian longsor dan erosi. Air hujan yang terinfiltrasi ke dalam tanah dan menjenuhi tanah menentukan terjadinya longsor, sedangkan pada kejadian erosi, air limpasan permukaan adalah unsur utama penyebab terjadinya erosi. Bedasarkan sejarah riset yang panjang, penting untuk menentukan batas intensitas dan frekuensi hujan saat akan menilai pengaruh curah hujan terhadap kegagalan suatu lereng. Hujan dengan curahan dan intensitas yang tinggi, misalnya $50 \mathrm{~mm}$ dalam waktu singkat $(<1$ jam), lebih berpotensi menyebabkan erosi dibanding hujan dengan curahan yang sama namun dalam waktu yang lebih lama (> 1 jam). Namun curah hujan yang sama tetapi berlangsung lama (> 6 jam) berpotensi menyebabkan longsor, karena pada kondisi tersebut dapat terjadi penjenuhan tanah oleh air yang meningkatkan massa tanah. Intensitas hujan menentukan besar kecilnya erosi, sedangkan longsor ditentukan oleh kondisi jenuh tanah oleh air hujan dan keruntuhan gesekan bidang luncur. Kegagalan lereng akibat hujan sangat ditentukan oleh proses infiltrasi/rembesan air, maka dari itu dibutuhkan pemahaman komprehensif mengenai distribusi tekanan air pori pada lereng tersebut. Pada tanah jenuh, hanya tekanan air pori positif yang terjadi. Hal ini berbeda dengan tanah tidak jenuh/jenuh sebagian, tanah dapat mengalami tekanan air pori negatif ketika berada diatas permukaan air, tetapi tanah juga dapat mengalami tekanan air pori positif pada saat terjadi infiltrasi. Tekanan adalah tegangan yang besarnya sama ke segala arah. Tekanan air pori positif berarti bisa diartikan sebagai tegangan pada celah-celah butiran tanah dengan arah tarik menuju semua butiran disekitarnya. Sedangkan tekanan air pori negatif bisa diartikan sebagai tegangan pada celah-celah butiran tanah dengan arah tekan dari semua butiran disekitarnya. Pada saat tekanan air pori positif, air akan mendorong butiran-butiran tanah disekitarnya yang membuat terjadinya mass movement. Sebaliknya pada saat tekanan air pori negatif, tekanan membuat gaya tarik antar molekul air semakin kuat sehingga akan timbul "rekatan" antar butiran tanah. 


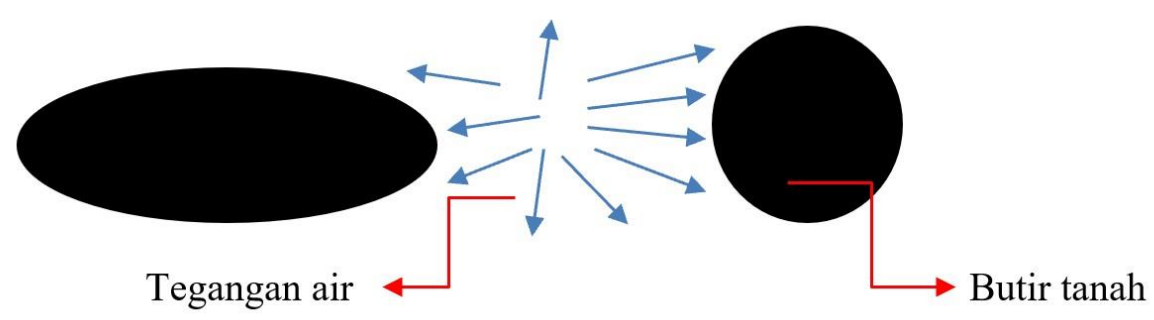

Gambar 2. Tekanan Air Pori Positif

Ketika hujan dan terjadi infiltrasi, tekanan air pori akan meningkat. Maka dari itu, peningkatan permukaan air tanah akibat hujan bisa dijadikan indikator peningkatan tekanan air pori positif. Tekanan air pori positif yang tinggi sering menjadi kunci terjadinya kegagalan suatu lereng (Chowdhury, R. N. \& Flentje, P. N., 2014). Di berbagai wilayah didunia, karakter suatu lereng bisa dilihat dari lapisan atas tanahnya. Faktor keamanan awal lereng dapat tinggi karena tekanan air pori masih negatif. Akan tetapi ketika air hujan turun dan mulainya proses infiltrasi, "rekatan" antar butiran tanah akan hilang tergantung dari koefisien permeabilitas tanah tidak jenuh tersebut. Kemudian faktor keamanan lereng akan berkurang di sepanjang tanah yang mengalami infiltrasi. Jadi pengamatan muka air tanah perlu direncanakan dengan baik sehingga diperoleh profil muka air tanah yang akurat. Adanya air dalam lereng menyebabkan turunnya kekuatan geser tanah atau massa batuan. Air tanah juga dapat menambah gaya-gaya yang menyebabkan ketidakstabilan.

\section{METODOLOGI PENELITIAN}

\section{Metode Pengumpulan Data}

Pada pengkajian teknis kali ini lokasi proyek yang ditinjau adalah salah satu proyek jalan di daerah Jambi. Data yang dikumpulkan adalah berdasarkan hasil peninjauan di lokasi proyek dengan mengumpulkan hasil uji tanah yang telah dilakukan. Data yang dikumpulkan adalah data hasil tes SPT (Standart Penetration Test) dan kondisi awal lereng. Kemudian hasil tes SPT akan dikorelasikan sesuai dengan kebutuhan desain metode pengendalian yang digunakan.

\section{Metode Analisis Data}

Sebelum dilakukannya analisis, dilakukan studi literatur terlebih dahulu unutk dapat memahami objek serta metodemetode yang akan diteliti. Studi literatur ini dilakukan melalui buku dan jurnal-jurnal. Hasil studi literatur digunakan sebagai landasan teori untuk mengkaji secara teknis stabilitas global. Metode analisis stabilitas lereng yang digunakan adalah metode elemen hingga, hal ini dikarenakan pemodelan dapat dilakukan secara kompleks serta dapat menampilkan tahapan konstruksi. Hasil analisis berupa grafik perbandingan angka keamanan sebelum dan setelah diberi perkuatan dengan variasi muka air tanah yang berbeda. 


\section{HASIL DAN PEMBAHASAN}

\section{Parameter Tanah}

Parameter tanah yang diperlukan dalam proses analisis didapat dari hasil uji laboratorium dan korelasi dari data tanah yang tersedia. Kesimpulan parameter tanah yang digunakan dalam proses analisis dapat dilihat pada Tabel 1.

Tabel 1. Kesimpulan Parameter Tanah

\begin{tabular}{ccccccccc}
\hline $\begin{array}{c}\text { Depth } \\
(\mathrm{m})\end{array}$ & Soil Type & Soil Consistency & $\begin{array}{c}\gamma_{\mathrm{sat}} \\
\left(\mathrm{kN} / \mathrm{m}^{3}\right)\end{array}$ & $\begin{array}{c}\mathrm{Su} \\
\left(\mathrm{kN} / \mathrm{m}^{2}\right)\end{array}$ & $\begin{array}{c}\mathrm{c}^{\prime} \\
\left(\mathrm{kN} / \mathrm{m}^{2}\right)\end{array}$ & $\begin{array}{c}\mathrm{E}^{\prime} \\
\left(\mathrm{kN} / \mathrm{m}^{2}\right)\end{array}$ & $\begin{array}{c}\phi \\
\left({ }^{\circ}\right)\end{array}$ & $u$ \\
\hline $0-2$ & Sand & Medium Dense & 19 & 0 & 0 & 25000 & 35 & 0,3 \\
\hline $2-4$ & Clay & Hard & 19 & 180 & 35 & 35000 & 29 & 0,3 \\
\hline $4-6$ & Clay & Hard & 19 & 300 & 60 & 59500 & 29 & 0,3 \\
\hline $6-8$ & Clay & Hard & 19 & 380 & 75 & 74000 & 29 & 0,3 \\
\hline $8-10$ & Clay & Very Hard & 19 & 380 & 75 & 74000 & 29 & 0,3 \\
\hline $10-12$ & Gravel & Very Dense & 22 & 0 & 0 & 74000 & 40 & 0,3 \\
\hline
\end{tabular}

\section{Beban Jalan}

Untuk pembebanan pada puncak lereng, terdapat beban lalu lintas jalan raya sepanjang 5,5 meter, jarak dari tepi lereng ke guard rail adalah 4,5 meter. Pembebanan lalu lintas jalan raya diambil beban merata statis sebesar $20 \mathrm{kPa}$. Gambar detail jalan raya dapat dilihat pada gambar 3 berikut

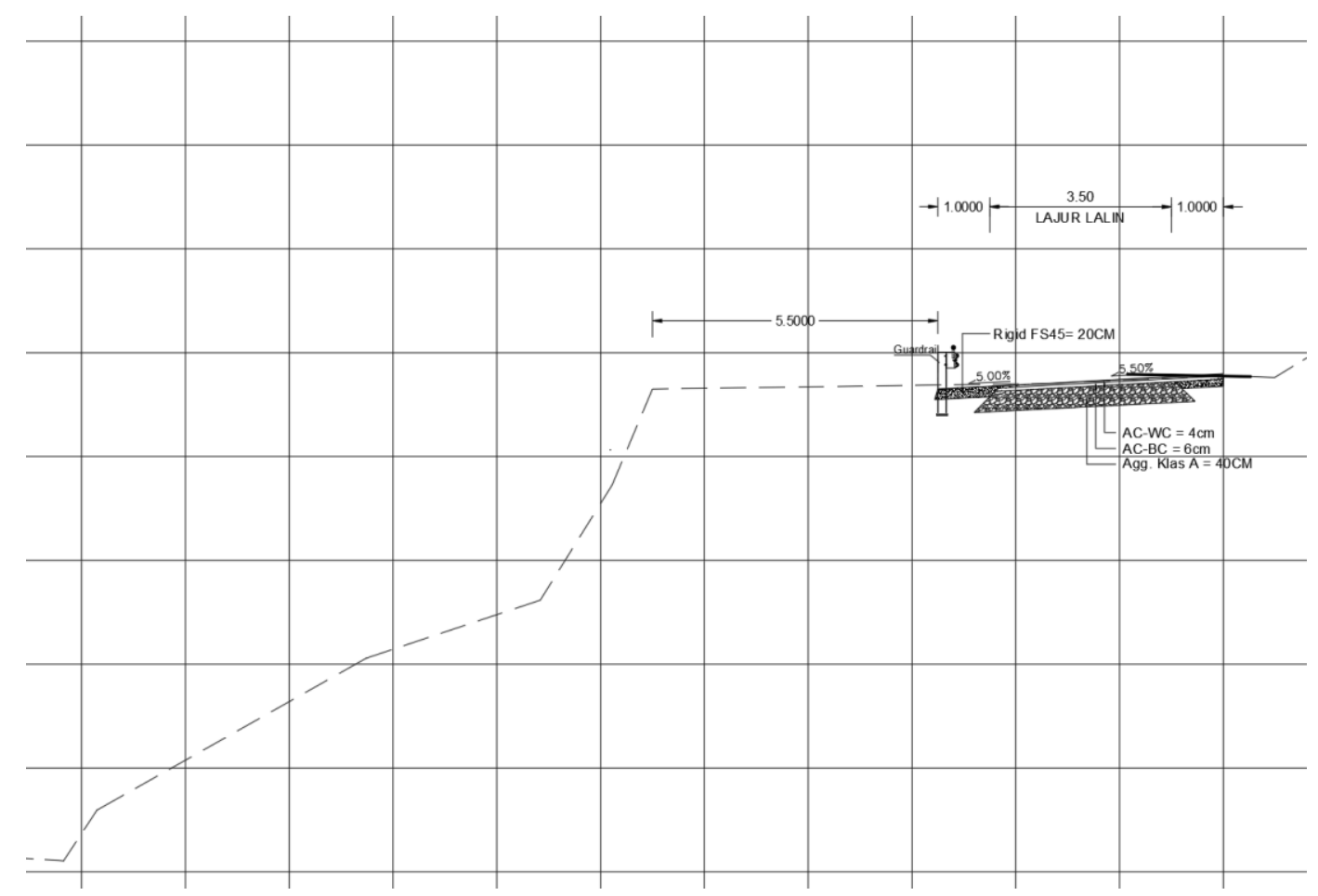

Gambar 3. Detail Pembebanan Jalan pada Puncak Lereng

\section{Bentuk Geometri Lereng Alami}

Lereng yang ditinjau adalah lereng alami pada proyek jalan di Jambi. Detail dimensi lereng dapat dilihat pada gambar 4 berikut. 


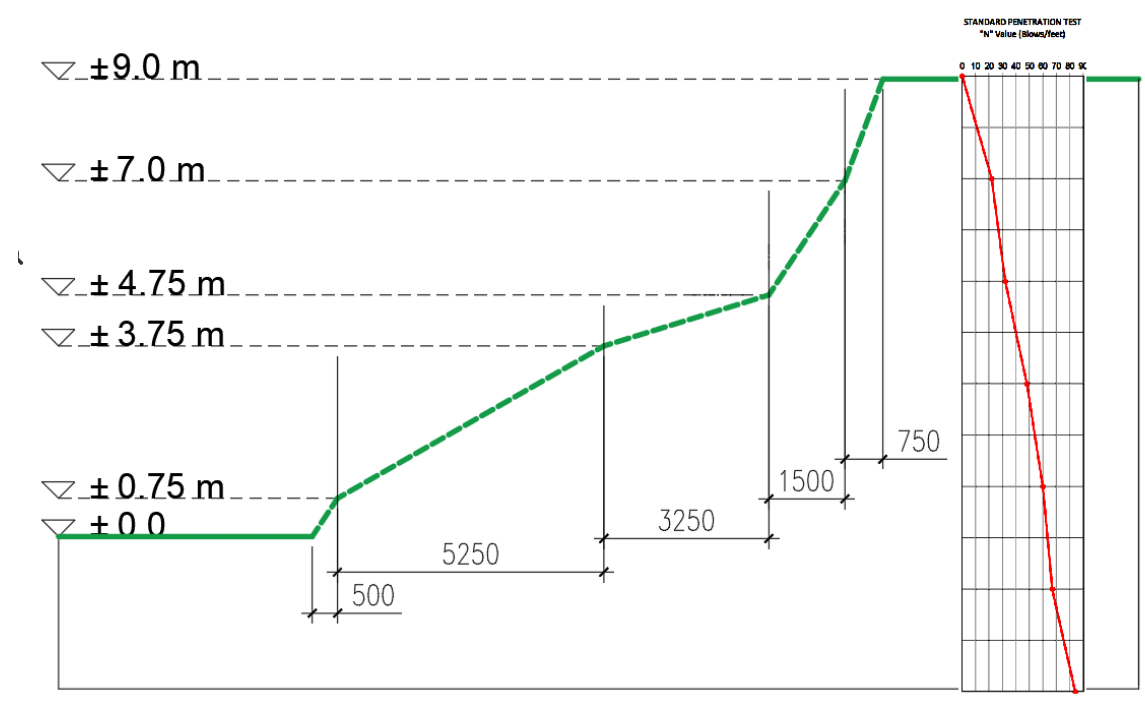

Gambar 4. Detail Geometri Lereng Awal

\section{Desain Struktur Perkuatan Tanah}

Terasering didesain dengan kemiringan sebesar $45^{\circ}$ dengan dibuat 4 buah terasering, masing-masing memiliki ketinggian 0,5 meter.

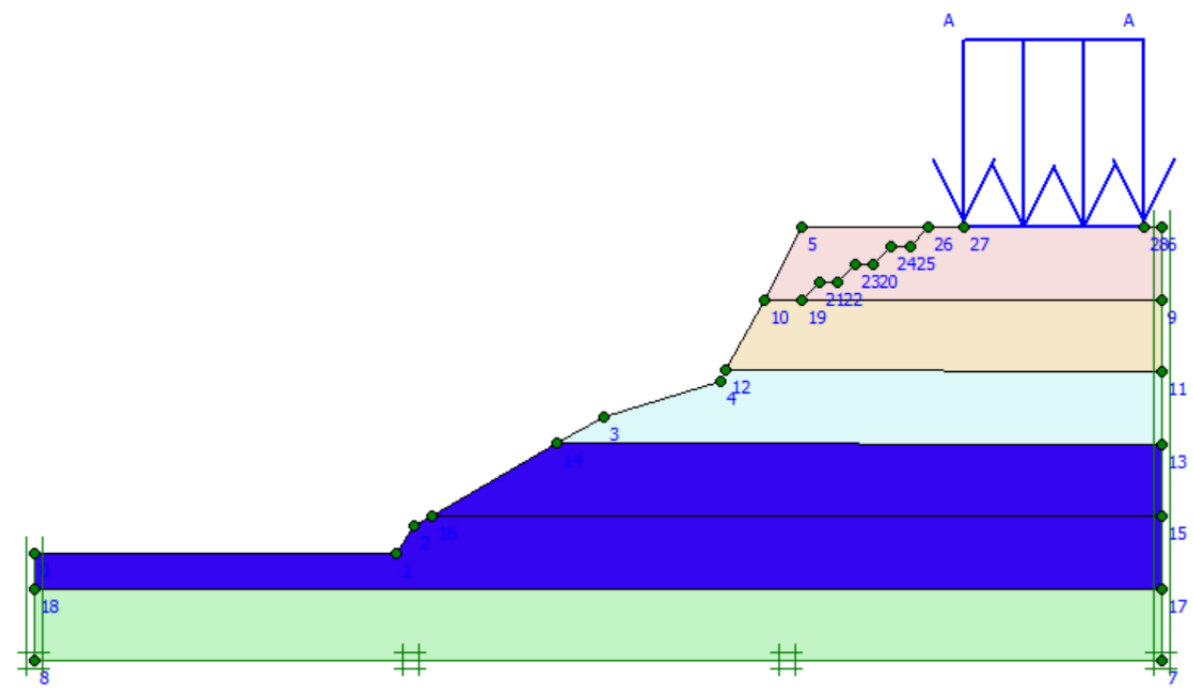

Gambar 5. Model Geometri Terasering

Bronjong didesain berdasarkan SNI 8460:2017 tentang persyaratan perancangan geoteknik dan modul pelaksanaan pekerjaan bronjong tahun 2012. Bronjong menggunakan Kawat Bronjong bentuk I kode E dengan lebar 1 meter, tinggi 0,5 meter, dan panjang $3 \mathrm{~m}$ dengan 2 sekat masing-masing berjarak 1 meter. Kemudian perbandingan bidang vertikal dan horizontal tiap lapis bronjong 1:1. Material pengisi kawat bronjong diggunakan batu kali. Parameter bronjong yang digunakan dalam desain sebagai berikut:
1. Sudut geser dalam $(\phi)$
2. Kohesi ( c')
3. Berat Isi Tanah $(\gamma)$
4. $\mathrm{E}$
5. v

$$
\begin{aligned}
& =45^{\circ} \\
& =\text { Mengikuti kohesi tanah dasar } \\
& =20 \mathrm{kN} / \mathrm{m}^{3} \\
& =100000\left(\mathrm{kN} / \mathrm{m}^{2}\right) \\
& =0,3
\end{aligned}
$$




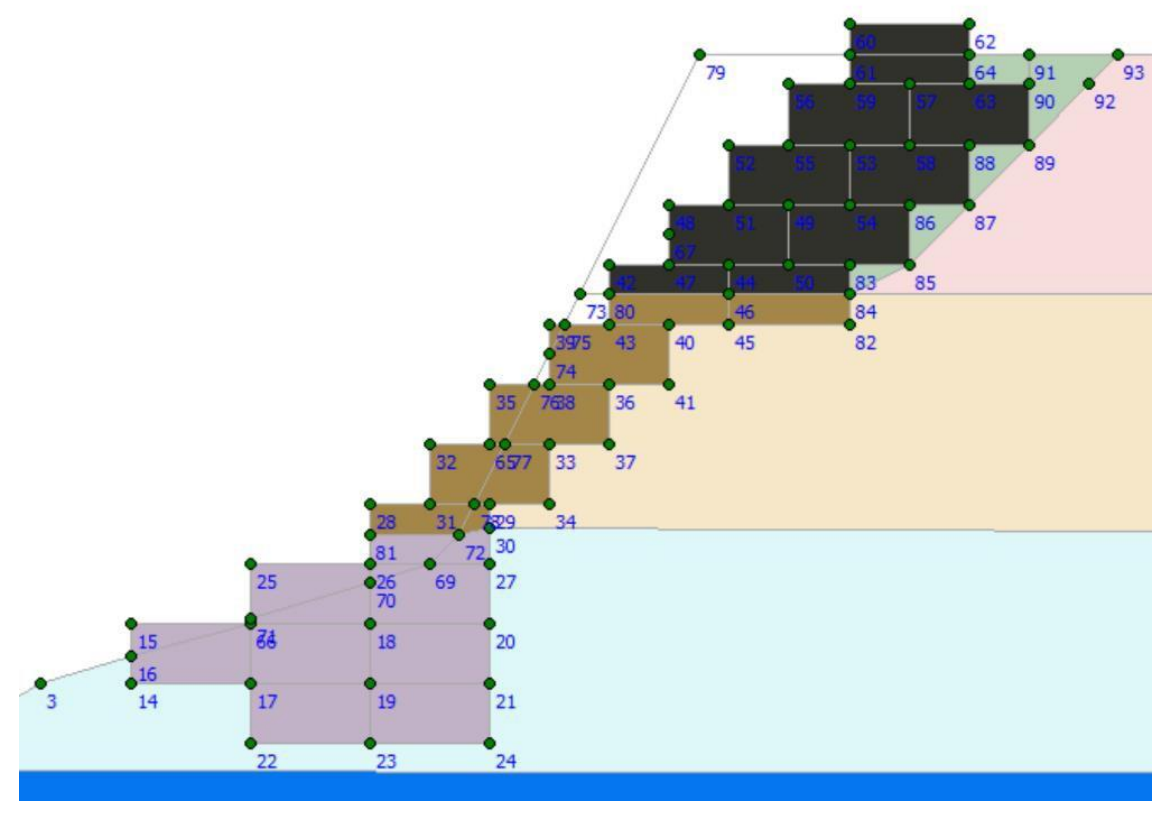

Gambar 6. Model Geometri Bronjong

Soil nailing didesain berdasarkan SNI 8460:2017 tentang persyaratan perancangan geoteknik. Dalam perhitungan digunakan parameter desain soil nailing sebagai berikut:

1. Nail bar digunakan BJTD 40 diameter $25 \mathrm{~mm}$, dengan panjang 1,0 $\mathrm{H}$ dan kemiringan nail $15^{\circ}$ dari sumbu horizontal. $\mathrm{H}=4,25 \mathrm{~m}$, maka panjang nail $=4,25$ meter.

2. Lubang bor untuk grouting berdiameter $200 \mathrm{~mm}$, dan grouting memiliki kuat tekan f'c $=25 \mathrm{MPa}$

3. Nail bar dipasang dengan pola segi empat, jarak vertikal dan horizontal nail 1 meter. Jarak nail dengan puncak lereng 0,5 meter.

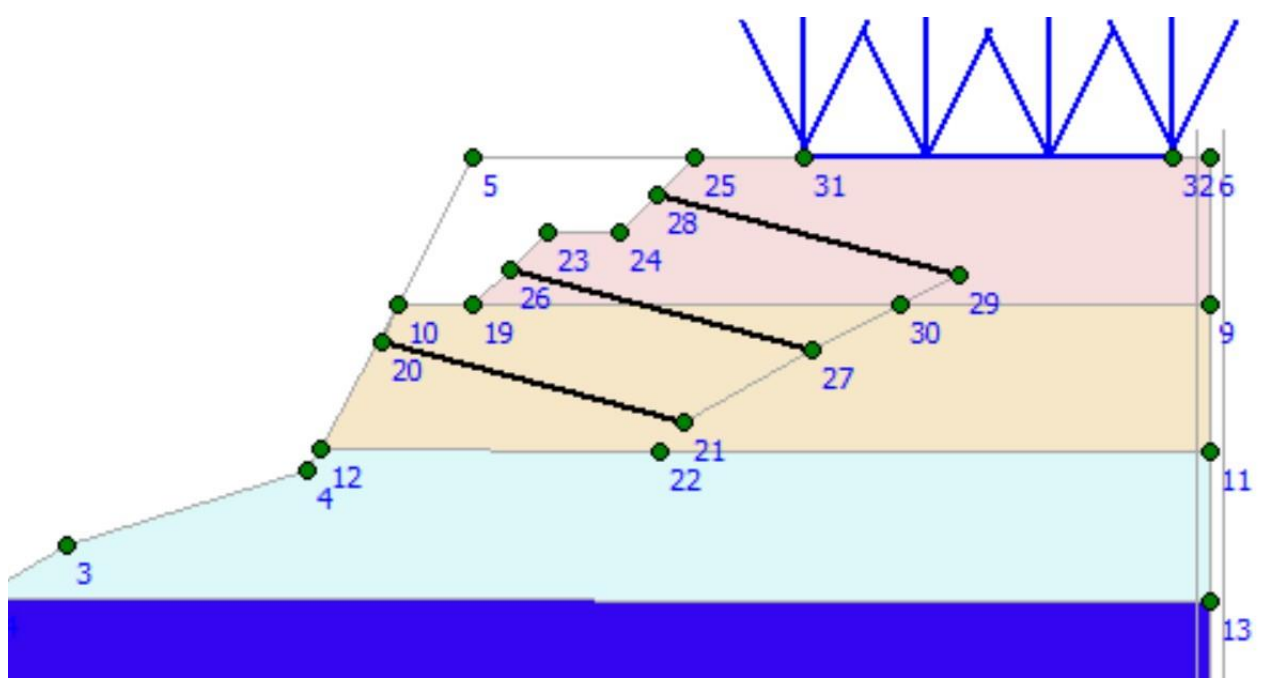

Gambar 7. Model Geometri Soil Nailing

Rumput vetiver atau akar wangi didesain berdasarkan Pedoman Standardisasi Nasional (PSN) No. 8, 2007 tentang Pedoman Penanaman Rumput vetiver untuk pengendalian erosi permukaan dan pencegahan longsoran dangkal pada lereng jalan. Rumput vetiver ditanam sebanyak 2 baris tiap setrip, dengan jarak antar baris sebesar $10 \mathrm{~cm}$ dan jarak antar setrip vetiver $40 \mathrm{~cm}$. 


\section{Analisis Angka Keamanan}

Pada bagian ini, akan dianalisis angka keamanan sebelum dan sesudah diberikan perkuatan terasering, bronjong, dan soil nailing. Analisis akan dikombinasikan dengan variasi muka air tanah. Pada analisis ini angka angka keamanan untuk minimum untuk proses konstruksi sementara diambil sebesar 1,25 dan untuk kondisi permanen diambil 1,5. Hasil analisis angka keamanan dapat dilihat pada Tabel 2 dan perbandingan angka keamanan tiap metode pengendalian dapat dilihat pada Gambar 8

Tabel 1. Angka Faktor Keamanan

\begin{tabular}{ccccc}
\hline & \multicolumn{4}{c}{ Angka keamanan } \\
\cline { 2 - 4 } Kedalaman MAT & Lereng Awal & \multicolumn{3}{c}{ Metode Pengendalian } \\
\cline { 2 - 4 } & 0,8779 & 1,7943 & 2,164 & 1,8024 \\
\hline $\begin{array}{c}\text { Normal } \\
(-2,0 \mathrm{~m})\end{array}$ & 0,8571 & 1,3211 & 2,147 & 1,5067 \\
\hline $\begin{array}{c}\text { Naik } 1 \mathrm{~m} \\
(-1,0 \mathrm{~m})\end{array}$ & 0,8554 & 1,065 & 2,1281 & 1,3496 \\
\hline $\begin{array}{c}\text { Naik } 2 \mathrm{~m} \\
(0)\end{array}$ & & & Bronjong \\
\hline
\end{tabular}

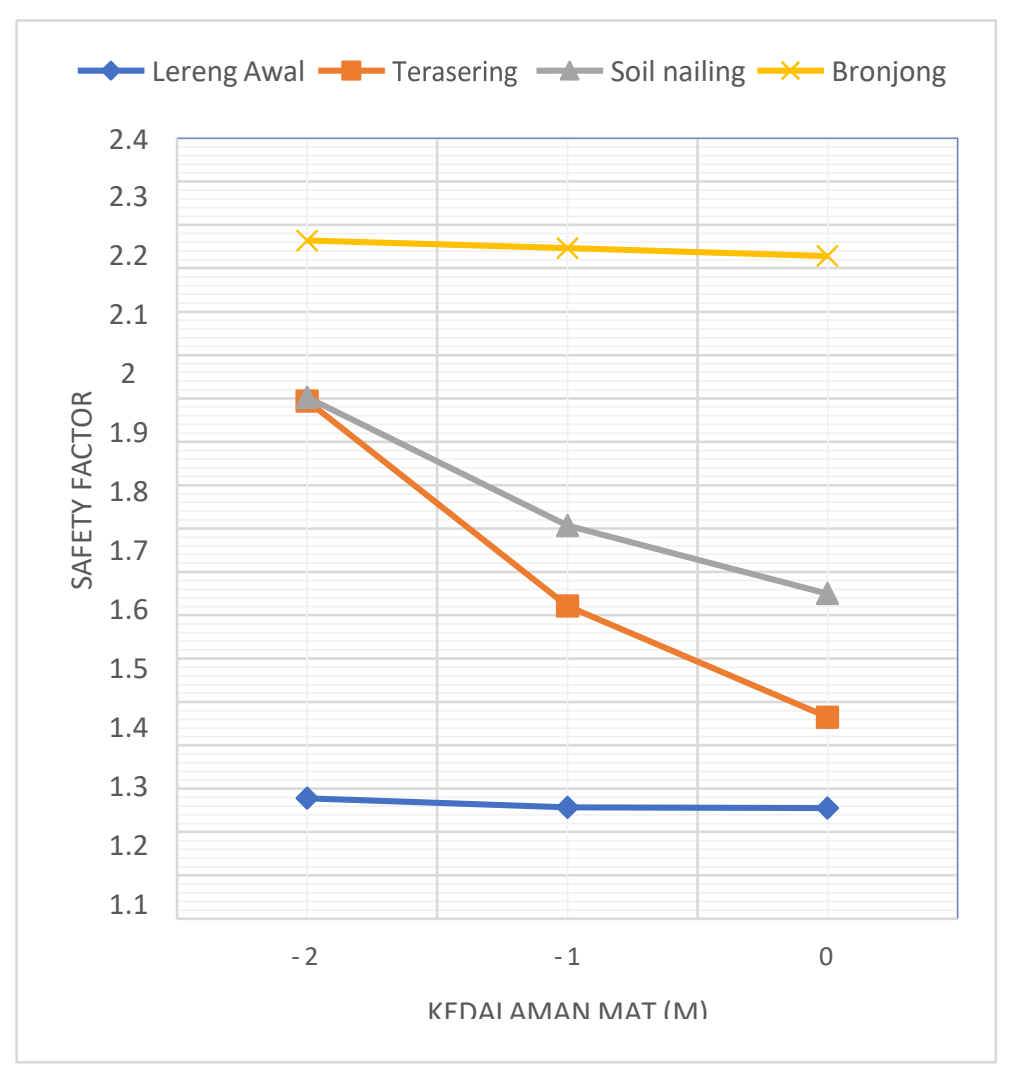

Gambar 8. Perbandingan Angka Keamanan Dengan Variasi Muka Air Tanah

Pada tabel diatas juga dapat dilihat berbagai angka angka keamanan pada setiap metode penanggulangan dengan muka air tanah yang bervariasi. Dari setiap metode dapat dilihat penurunan angka angka keamanan yang sebanding dengan kenaikan muka air tanah, hal ini menunjukan hubungan angka angka keamanan dengan kedalaman muka air tanah. 
Keberadaan air dalam lapisan tanah sangat berpengaruh terhadap stabilitas lereng dan dapat membahayakan lingkungan disekitar lereng, hal ini dapat dilihat pada konstruksi terasering dan soil nailing, lereng akan aman pada kondisi MAT normal, akan tetapi lereng dapat mengalami kegagalan apabila terjadi hujan terus menerus yang dapat menaikkan MAT. Penurunan ini dikarenakan kekuatan tanah akan berkurang seiring dengan tingginya MAT pada lereng. Adanya MAT akan memberi dampak besar sebagai tenaga pendorong pada lereng sehingga menjadi penyebab dominan longsornya lereng. Semakin tinggi MAT pada lereng maka semakin besar pula gaya dorong yang dihasilkan untuk meruntuhkan lereng tersebut. Perubahan tinggi MAT akan menambah beban pada lereng tersebut. MAT yang fluktuatif inilah yang akan melunakkan lapisan tanah pada lereng sehingga parameter tanah seperti nilai kohesi dan sudut geser dalam tanah tereduksi dan tidak mampu untuk menahan longsoran. Pada akhirnya MAT pada lereng sangat berpengaruh terhadap kestabilan lereng. Semakin tinggi MAT pada lereng maka nilai faktor keamanan (SF) akan berkurang. Dalam hal ini lereng dengan MAT tinggi menjadikan tanah pada lereng tersebut dalam kondisi jenuh, sehingga kekuatan geser tanah berkurang. Begitu juga sebaliknya, lereng dengan MAT rendah atau tanah dalam kondisi kering maka angka keamanannya akan meningkat.

Lereng awal dengan kondisi tanah asli dan kondisi MAT yang dimodifikasi menghasilkan angka angka keamanan di bawah 1,5. Hal ini menunjukan bahwa lereng tersebut memerlukan stabilisasi lereng tambahan.

Lereng dengan perkuatan terasering pada muka air normal menghasilkan angka angka keamanan di atas 1,5, hal ini menunjukan bahwa lereng tersebut stabil pada kondisi tersebut. Akan tetapi pada saat MAT dinaikan angka angka keamanan akan berkurang menjadi dibawah 1,5, hal ini menunjukan bahwa lereng akan menjadi tidak stabil ketika mengalami kenaikan muka air tanah. Untuk mendapatkan angka angka keamanan yang lebih tinggi, bentuk geometri terasering harus dibuat lebih landai. Akan tetapi pada kasus ini, pemodelan geometri terasering tidak dianjurkan dibuat lebih landai dikarenakan akan menggunakan lahan konstruksi jalan disamping lereng.

Lereng dengan perkuatan bronjong pada muka air normal dan pada muka air yang sudah dimodifikasi menghasilkan angka angka keamanan di atas 1,5, hal ini menunjukan bahwa lereng tersebut akan tetap stabil pada kondisi normal maupun pada saat kondisi muka air tanah naik.

Lereng dengan perkuatan soil nailing pada muka air normal dan muka air naik $1 \mathrm{~m}$ menghasilkan angka angka keamanan diatas 1,5, hal ini menunjukkan bahwa lereng tersebut stabil pada kondisi tersebut. Akan tetapi pada saat muka air tanah dinaikan $2 \mathrm{~m}$, angka angka keamanan akan berkurang menjadi dibawah 1,5, hal ini menunjukkan bahwa lereng akan menjadi tidak stabil ketika mengalami kenaikan muka air tanah. Untuk mendapatkan angka angka keamanan yang lebih tinggi pada konstruksi soil nailing, dapat dilakukan dengan memperpanjang nailing, memperbesar lubang bor untuk grouting, menaikkan mutu baja dan/atau beton grouting, memperbanyak nailing, membuat jarak antar nailing lebih rapat, dll. Akan tetapi pada kasus ini, pemanjangan nailing menjadi 1,2 $\mathrm{H}$ maupun menaikkan mutu beton tidak dilakukan, karena peningkatan angka angka keamanan tidak signifikan. Kemudian jarak antar nailing juga tidak dianjurkan dibuat lebih rapat karena akan mempersulit proses konstruksi. Perbaikan kekuatan tambahan pada soil nailing disarankan dilakukan dengan memasang Vertical drain strip, Vertical drain strip dengan lebar $300 \mathrm{~mm}$ - $400 \mathrm{~mm}$ dipasang di belakang dinding muka dan menempel pada permukaan tanah. Vertical drain strip dapat dipasang dari permukaan atas lereng sampai dasar galian lereng. Hal ini akan membuat kenaikan muka air tanah di sekitar lereng akan terminimalisir, sehingga lereng akan lebih stabil meskipun terjadi hujan terus menerus yang dapat menaikkan muka air tanah.

Konstruksi Bronjong paling cocok untuk digunakan pada kasus ini, hal ini dikarenakan bronjong lebih stabil terhadap fluktuasi MAT. Bronjong dapat lebih stabil terhadap fluktuasi MAT karena dapat menahan erosi tanah yang terjadi pada lereng dan mampu menambah kuat geser lereng tersebut.

\section{KESIMPULAN}

Berdasarkan kajian teknis, analisis, dan pembahasan dari proyek konstruksi jalan di sungai Manau batas Kerinci, provinsi Jambi, dapat disimpulkan bahwa:

1. Lereng pada proyek memerlukan metode-metode penanggulangan longsor dikarenakan hasil analisis pada kondisi awal lereng menggunakan program elemen hingga didapatkan angka angka keamanan sebesar 0,8779. Dimana angka tersebut tidak aman untuk kondisi lereng permanen. Nilai angka keamanan yang baik yaitu lebih besar dari 1,5 .

2. Pada hasil analisis disimpulkan bahwa kedalaman MAT sangat berpengaruh terhadap kestabilan lereng. Hal ini dapat dilihat pada pengurangan hasil angka angka keamanan pada saat dilakukan variasi terhadap MAT pada bab sebelumnya. Hal ini juga menunjukan bahwa iklim merupakan salah satu faktor dominan terjadinya kelongsoran tanah.

3. Ada tiga metode yang digunakan pada analisis kestabilan lereng, yaitu terasering, bronjong, dan soil nailing. Dari hasil analisis yang sudah dilakukan, metode tersebut dapat diaplikasian pada lereng alami. Hal ini dilihat 
dari peningkatan angka angka keamanan sesudah lereng diberikan konstruksi perkuatan tersbut. Namun dalam penggunaannya disesuaikan dengan kebutuhan lapangan dan kemampuan pelaksanaan konstruksi.

4. Konstruksi Bronjong digunakan pada kasus ini, hal ini dikarenakan bronjong lebih stabil terhadap fluktuasi MAT. Bronjong dapat lebih stabil terhadap fluktuasi MAT karena dapat menahan erosi tanah yang terjadi pada lereng dan mampu menambah kuat geser lereng tersebut. Kemudian pada bagian permukaan lereng yang tidak terdapat perkuatan, ditanami rumput vetiver sebagai upaya tambahan untuk mencegah erosi.

\section{DAFTAR PUSTAKA}

Abe, K. and Ziemer, R.R., 1991. Effect of tree roots on a shear zone: modeling reinforced shear stress. Canadian Journal of Forest Research.

Bischetti, G.B. and Chiaradia, E.A., 2004. Evaluation of the effect of root cohesion on slope failures in St.Giulio creek catchment. Book of Abstracts - International Conference on ECO-ENGINEERING "The use of vegetation to improve slope stability". 13. - 17. Sept.2004, Thessaloniki, Greece.

Pedoman Standardisasi Nasional (PSN) No. 8, 2007, Pedoman Penanaman Rumput vetiver untuk pengendalian erosi permukaan dan pencegahan longsoran dangkal pada lereng jalan.

Peraturan Menteri Pertanian: 47/Permentan/OT.140/10/2006 tentang Pedoman Umum Budidaya Pertanian Pada Lahan Pegunungan.

Badan Standarisasi Nasional. SNI 8460:2017 Persyaratan Perancangan Geoteknik. 2017. Jakarta: BSN Standar Nasional Indonesia 8460:2017 tentang Persyaratan Perancangan Geoteknik.

Standar Nasional Indonesia 03-0090-1999 tentang Bronjong Kawat.

Steinacher, R., 2009. The Influence of Deforestation on Slope (In-) Stability, Austria.

Tsukamoto, Y., 1990. Effect of vegetation on debris slide occu-rences on steep forested slopes in Japan islands. International Association of Hydrological Sciences Publication. 